\title{
ANALISIS PROSES PEMBELAJARAN PENDEKATAN SAINTIFIK DALAM KURIKULUM 2013 DI KELAS II SDN JATIDUKUH MOJOKERTO
}

\author{
Reninda Dewi Pinar \\ reninda.dewi.p@gmail.com \\ Universitas Abdurachman Saleh Situbondo
}

\begin{abstract}
Abstrak: Peneliti memiliki ketertarikan pada pendekatan pembelajaran yang terdapat di kurikulum 2013, yaitu pendekatan saintifif (scientific approach). Penelitian ini dilaksanakan di SDN Jatidukuh Mojokerto kelas II. Tujuan dari penelitian ini adalah untuk mengetahui perencanaan, proses, dan penilaian pembelajaran dengan pendekatan saintifik sserta kendala-kendala dalam kegiatan belajarnya. Penelitian ini menggunakan pendekatan kualitatif, teknik pengumpulan data yang digunakan adalah observasi, wawancara, dan dokumentasi. Analisis data dalam penelitian ini menggunakan model Miles and Huberman (1992). Hasil penelitian ini adalah (1) guru tidak menyusun RPP sendiri, (2) pelaksanaan pembelajaran belum maksimal, (3) penilaian pembelajaran belum dilaksanakan sesuai dengan pedoman penilaian yang terdapat di kurikulum 2013. Kendala-kendala yang dihadapi guru maupun siswa adalah (1) terbatasnya waktu, (2) kurangnya pemahaman tentang pendekatan saintifik, (3) terbatasnya sumber belajar, dan (4) penggunaan pembelajaran konvensional yang sulit untuk dihilangkan karena belum terbiasa. Maka dari itu perlu adanya monitoring dari kepala sekolah agar mampu meningkatkan kemampuan guru dalam mengajar.
\end{abstract}

Kata kunci: proses pembelajaran, pendekatan saintifik, kurikulum 2013

\section{ANALYSIS ON LEARNING PROCESS' USING THE SAINTIFIC APPROACH OF CURRICULUM 2013 IN GRADE II ELEMENTARY SCHOOL JATIDUKUH MOJOKERTO}

\begin{abstract}
Researchers have an interest in learning in the 2013 curriculum, which discusses the scientific approach. This research was conducted at elementary School of Jatidukuh Mojokerto class II. The purpose of this study is to determine the planning, process, and assessment of learning with a scientific approach as well as the constraints in learning activities.. This study uses qualitative, data collection techniques used are observation, interviews, and documentation. Analysis of the data in this study used the field model of Miles and Huberman (1992). The results of this study are (1) teachers do not prepare their own lesson plans, (2) the implementation of learning has not been maximized, (3) learning has not been carried out in accordance with the lessons discussed in the 2013 curriculum. The constraints faced by both teachers and students are (1) limited
\end{abstract}


Reninda, Analisis Proses Pembelajaran Pendekatan... time, (2) lack of understanding of the scientific approach, (3) limited learning resources, and (4) the use of conventional learning that is difficult to eliminate because it is not used. Therefore there is a need for monitoring from the school principal to be able to improve the ability of teachers in teaching.

Keywords: learning process, scientific approach, curriculum of 2013.

\section{PENDAHULUAN}

Pendidikan merupakan salah satu kebutuhan manusia. Pendidikan merupakan sebuah pembelajaran untuk memeroleh pengetahuan, keterampilan, dan kebiasaan sekelompok orang yang akan dilanjutkan dari satu generasi ke generasi berikutnya. Pendidikan dapat diperoleh melalui kegiatan pengajaran, pelatihan, atau penelitian. Pendidikan berkaitan dengan proses belajar, yakni sebuah upaya perubahan dan perbaikan yang bertujuan membawa kualitas pendidikan Indonesia lebih baik. Perubahan dan perbaikan dalam bidang pendidikan meliputi berbagai komponen yang terlibat di dalamnya baik itu pelaksana di lapangan (kompetensi guru dan kualitas tenaga pendidik), mutu pendidikan, kurikulum, sarana dan prasarana pendidikan serta pendekatan maupun strategi pembelajaran.

Dalam rangka mencerdaskan kehidupan bangsa, maka peningkatan mutu pendidikan suatu hal yang sangat penting bagi pembangunan berkelanjutan di segala aspek kehidupan manusia. Memasuki masa era globalisasi, bangsa Indonesia tidak matimatinya selalu melakukan pembangunan disegala bidang kehidupan baik pembangunan material maupun spiritual termasuk di dalamnya sumber daya manusia, salah satu faktor yang menunjang pembangunan atau peningkatan sumber daya manusia yaitu melalui pendidikan mendapat prioritas utama.

Dalam proses belajar mengajar guru dituntut untuk dapat mewujudkan dan menciptakan situasi yang memungkinkan siswa untuk aktif dan kreatif. Pada kegiatan belajar mengajar diharapkan peserta didik dapat secara optimal melaksanakan aktivitas belajar sehingga tujuan pembelajaran yang telah ditetapkan dapat tercapai secara maksimal. Proses pembelajaran dapat didefinisikan untuk menjalin hubungan, mengidentifikasi pola-pola belajar, mengorganisasikan bagian-bagian kecil pengetahuan, perilaku, aktivitas yang semula tidak berkaitan, menjadi suatu pola baru yang utuh menyeluruh bagi peserta didik. 
Reninda, Analisis Proses Pembelajaran Pendekatan...

Pada proses pembelajaran terdapat beberapa cara, teknik, model, metode, strategi, dan pendekatan serta sumber belajar di dalamnya. Cara yang digunakan dalam kegiatan pembelajarang terkadang dirasa belum mampu untuk mengaktifkan, memaksimalkan proses pembelajaran, sehingga tenaga pendidik harus mampu menggabungkan atau mengkombinasikan antara model, strategi, metode, ataupun pendekatan pembelajaran. Dalam kaitannya dengan proses pembelajaran, terdapat peraturan baru tentang seperangkat rencana dalam penyelenggaraan kegiatan pembelajaran, atau yang biasanya disebut dengan kurikulum. Kurikulum yang sedang diperbincangkan di dunia pendidikan Indonesia adalah kurikulum 2013. Pada kurikulum 2013 ini terdapat beberapa pengembangan, salah satunya adalah tentang standar proses pembelajaran.

Proses pembelajaran dalam kurikulum 2013, berlangsung dengan memadukan penalaran induktif dan penalaran deduktif. Perpaduan penalaran induktif dan penalaran deduktif ini biasa disebut dengan pendekatan saintifik (scientific approach). Pembaharuan pada kurikulum 2013 dirasa cukup banyak, selain dari proses pembelajarannya. Pada kurikulum 2013 menekankan pada peningkatan dan keseimbangan soft skill dan hard skills yang meliputi aspek kompetensi sikap, pengetahuan, dan keterampilan. Pembaharuan proses pembelajaran kurikulum 2013 terletak pada pembelajaran yang menekankan pada dimensi pedagogic modern, yaitu menggunakan pendekatan saintifik. Langkah-langkah pendekatan saintifik dalam proses pembelajaran meliptu menggali informasi melalui pengamatan, bertanya, percobaan, kemudian mengolah data atau informasi, menyajikan data atau informasi, dilanjutkan dengan menganalisis, menalar, kemudian menyimpulkan, dan mencipta (Daryanto, 2014) dan (Akbar, 2013 dalam Afandi, 2019).

Pendekatan saintifik adalah pendekatan yang digunakan dalam pembelajaran melalui proses ilmiah. Apa yang dipelajari dan diperoleh peserta didik dilakukan dengan indera dan akal pikiran sendiri, sehingga mereka mengalami secara langsung dalam proses mendapatkan ilmu pengetahuan. Pendekatan saintifik diharapakan mampu memberikan bekal untuk menghadapi dan memecahkan masalah yang dihadapi oleh peserta didik di masa yang akan datang.

Pembaharuan lainnya yang terlihat jelas dalam kurikulum 2013 adalah penggunaan penilaian autentik (authentic assesment) umtuk mengukur hasil belajar peserta didik. Penilaian autentik adalah pengukuran yang bermakna secara signifikan atas 
Reninda, Analisis Proses Pembelajaran Pendekatan... hasil belajar peserta didik umtuk ranah sikap, keterampilan, dan pengetahuan (Hosnan, 2014). Jenis penilaian autentik adalah penilaian kinerja, evaluasi diri, esai, proyek, dan portofolio. Penilaian semacam ini mampu menggambarkan seluruh aspek yang terdapat dalam diri peserta didik dalam proses pembelajaran.

Dalam menyikapi beberapa keluhan tenaga pendidik akan beban kerja setelah adanya pembaharuan kurikulum, pemerintah telah menyiapkan solusi terkait kekhawatiran dari tenaga pendidik. Upaya pemerintah untuk meringakan beban guru adalah menyediakan buku pegangan bagi guru. Dalam hal ini sudah ada pemetaan SK dan KI (Kompetensi Inti), lamgkah-langkah pembelajaran yang dilakukan guru untuk setiap pembelajaran, serta rubric penilaian yang digunakan untuk menilai aktivitas siswa. Hal ini diharapkan dapat membantu mempermudah guru dalam pembuatan perencanaan pembelajaran dan menghilangkan kekhawatiran para guru akan beban pekerjaan yang ditanggung.

Salah satu SD di Kecamatan Gondang Kabupaten Mojokerto yang menerapkan kurikulum 2013 sejak 2017 hingga sekarang. Kelas yang sudah menerapkan kurikulum 2013 adalah kelas I, II, IV, dan V.

Berdasarkan hasil wawancara dengan Kepala Sekolah SDN Jatidukuh Mojokerto pada tanggal 18 maret 2019 terkait bagaimana implementasi atau penerapan pendekatan saintifik pada kurikulum 2013 dalam proses belajar mengajar di SDN Jatidukuh Mojokerto. Beliau menginformasikan bahwa sekolah ini sudah menerapkan kurikulum 2013 yang di dalamnya harus ada kegiatan sesuai tahapan pendekatan saintifik, tetapi memang banyak kendala atau hambatan saat menerapkan pendekatan tersebut. Padahal hampir semua guru sudah diikut-sertakan dalam berbagai kegiatan pelatihan terkait kurikulum 2013 dan pendekatan saintifik. Berdasarkan hal ini, peneliti melakukan observasi di kelas II SDN Jatidukuh Mojokerto. Alasan lain peneliti melakukan observasi di kelas II adalah karena kelas II dirasa sudah mampu untuk diajak berdialog ataupun berkomunikasi dengan cukup baik dibandingkan kelas I, karena awalnya peneliti ingin meneliti kelas I, tetapi setelah sedikit berbincang dengan guru kelas I, guru tersebut menyarankan untuk ke kelas II saja. Sehingga akhirnya peneliti memilih kelas II sesuai saran guru kelas I dan juga guru kelas II mengijinkan peneliti untuk melakukan kegiatan observasi di kelasnya. 
Reninda, Analisis Proses Pembelajaran Pendekatan...

Sebelum melakukan observasi, peneliti mewawancarai guru kelas II terkait rencana pelaksanaan pembelajaran yang digunakan, karakteristik peserta didik, proses pembelajaran yang selama ini dilakukan, media yang digunakan dan lain sebagainya. Guru kelas II menjelaskan mengalami kesulitan dalam penyusunan RPP, implementasi pendekatan saintifik, dan media yang terbatas, serta kemampuan peserta didik dalam menerima pembaharuan pembelajaran. Guru juga mengaku sering terkendala dalam mengalokasikan waktu pada saat proses pelaksanaan pembelajaran dikarenakan banyaknya kegiatan dalam satu kali pertemuan, sehingga menyebabkan proses pembelajaran kurang efektif.

Berdasarkan uraian masalah di atas, peneliti tertarik untuk melihat lebih jauh bagaimana proses pembelajaran dalam pendekatan saintifik dalam kurikulum 2013 pada siswa kelas II SDN Jatidukuh Mojokerto. Secara khusus, tujuan penelitian ini adalah untuk mengungkap bagaimana perencanaan, pelaksanaan, dan bentuk evaluasi pembelajaran di kelas tersebut. Selain itu, berdasarkan wawancara dengan Kepala Sekolah SDN Jatidukuh, kelas II belum pernah digunakan sebagai tempat penelitian terkait dengan penerapan pembelajaran dalam pendekatan saintifik dalam kurikulum 2013.

\section{METODE}

Penelitian ini menggunakan pendekatan penelitian kualitatif yang merupakan suatu bentuk penelitian yang bersifat dekriptif kualitatif. Penelitian ini bertujuan untuk mendeskripsikan hasil pengolahan data yang berupa kata-kata, gambaran umum yang terjadi di lapangan. Penelitian kualitatif digunakan untuk memahami realitas sosial, yaitu melihat dunia dari apa adanya, bukan dunia yang seharusnya. Penelitian kualitatif dilakukan pada kondisi alamiah dan bersifat penemuan (Arikunto 2006, Sugiyono, 2016). Dalam penelitian di menggunakan teknik pengumpulan data dengan cara melakukan wawancara, observasi, dan dokumentasi. berikut ini adalah kisi-kisi pertanyaan wawancara.

Tabel 1. Daftar Pertanyaan Wawancara Guru Kelas II SDN Jatidukuh

\begin{tabular}{|c|l|}
\hline No & \multicolumn{1}{|c|}{ Pertanyaan } \\
\hline \multirow{2}{*}{1} & $\begin{array}{l}\text { Aspek Perencanaan pembelajaran kurikulum 2013 } \\
\text { 1. Apakah Ibu menyusun sendiri RPP yang akan digunakan dalam pembelajaran? } \\
\text { 2. Apakah Ibu menggambarkan pendekatan saintifik dalam RPP? }\end{array}$ \\
\hline
\end{tabular}


Reninda, Analisis Proses Pembelajaran Pendekatan...

\begin{tabular}{|c|l|}
\hline No & \multicolumn{1}{c|}{ Pertanyaan } \\
\hline & $\begin{array}{l}\text { 3. Apakah Ibu menuliskan rancangan penilaian yang akan digunakan dalam proses } \\
\text { pembelajaran pada RPP? }\end{array}$ \\
\hline 4. Bagaimana Ibu menentukan sumber belajar di setiap pertemuan?
\end{tabular}

Sedangkan analisis data pada penelitian ini menggunakan analisis data selama dilapangan dengan model Miles and Huberman (1992). Model Miles and Huberman terdiri dari tahapan penggolongan data/reduksi data, penyajian data, dan verifikasi data. Berikut gambar dari model Miles and Huberman dalam penelitian kualitatif.

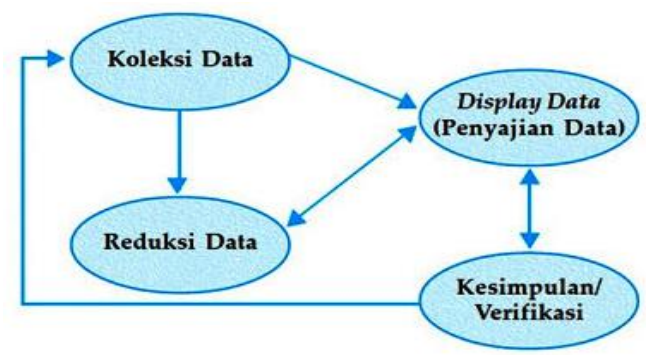

Gambar 1. Analisis Data Model Miles and Huberman (1992)

\section{HASIL}

Penelitian yang dilakukan peneliti tentang analisis proses pembelajaran pendekatan saintifik dalam kurikulum 2013 di kelas II SDN Jatidukuh Mojokerto meliputi perencanaan pembelajaran, pelaksanaan pembelajaran, dan kendala yang dihadapi guru saat kegiatan belajar mengajar. Hasil penelitian yang dilakukan peneliti adalah sebagai berikut ini.

\section{Aspek Perencanaan Pembelajaran}

Berdasarkan wawancara, kegiatan perencanaan pembelajaran yang dilakukan oleh guru tidak menyusun RPP sesuai dengan kurikulum 2013, hal ini juga sesuai dengan hasil wawancara yang dilakukan oleh peneliti dengan guru kelas II seperti di bawah ini. 
Reninda, Analisis Proses Pembelajaran Pendekatan...

Peneliti : "Apakah Ibu menyusun sendiri RPP yang akan digunakan dalam pembelajaran?".

Guru : "Yidak mbak, karena saya terkendala oleh waktu, sehingga RPP yang saya tunjukkan hasil download dari internet".

Berdasarkan hasil analisis Rencana Pelaksanaan Pembelajaran (RPP) yang ditunjukkan guru kepada peneliti, RPP tersebut sudah mengarah kepada pembelajaran dengan pendekatan saintifik, tetapi tahap kegiatan 5M belum diberikan keterangan dalam tanda kurung. Peneliti mencoba kembali mengajukan pertanyaan terkait RPP yang ditunjukkan. Wawancaranya adalah sebagai berikut.

Peneliti : "Apakah Ibu melihat atau mencermati RPP, sebelum kegiatan belajar mengajar dilakukan?".

Guru : "Kadang-kadang mbak".

Pernyataan kepada kepala sekolah dalam catatan wawancara memberikan penguatan bahwa guru tidak membuat sendiri Rencana Pelaksanaan Pembelajaran (RPP). Adapun catatan wawancara tersebut adalah sebagai berikut ini.

Peneliti : "Bagaimana penyusunan Rencana Pelaksanaan Pembelajaran (RPP) di sekolah ini Pak?". Kepala sekolah : "Sebenarnya saya menginginkan guru-guru untuk membuat RPP, boleh mengambil dari google tetapi harus dicermati, direvisi, ditelaah, dan dikembangkan sendiri. Saya memperbolehkan dengan pertimbangan waktu yang dimiliki guru, karena selain membuat RPP guru juga mempunyai kewajiban mengajar dan mengisi administrasi-administrasi yang lainnya".

Dari hasil wawancara peneliti dengan kepala sekolah, beliau tidak ingin terlalu membebani guru-guru dengan tugas pembuatan RPP, dimana untuk kurikulum 2013 dengan pendekatan saintifik ini dirasa memang sedikit agak menguras pikiran, baik dari kegiatan awal hingga evaluasi.

Dari wawancara tersebut diperoleh informasi bahwa, kepala sekolah memperbolehkan guru-guru tidak menyusun sendiri RPP dengan catatan copy paste tapi harus dikembangkan sendiri. Berikut ini adalah tabel komponen RPP yang ditunjukkan oleh Ibu Ety selaku guru kelas II SDN Jatidukuh Mojokerto.

Selain data-data dari hasil wawancara terkait perencanaan pembelajaran, peneliti juga melakukan observasi pada komponen RPP yang digunakan berdasarkan Permendikbud No 22 Tahun 2016 tentang Standar Proses. Berikut dipaparkan hasilnya.

Tabel 2. Hasil Observasi pada Komponen RPP

\begin{tabular}{|l|l|l|}
\hline No & \multicolumn{1}{|c|}{ Komponen RPP } & \multicolumn{1}{c|}{ Keterangan } \\
\hline 1 & Identitas sekolah & $\begin{array}{l}\text { Identitas sekolah dituliskan dengan } \\
\text { mencantumkan nama satuan pendidikan yaitu } \\
\text { SDN Jatidukuh Mojokerto. }\end{array}$ \\
\hline
\end{tabular}


Reninda, Analisis Proses Pembelajaran Pendekatan...

\begin{tabular}{|c|c|c|}
\hline No & Komponen RPP & Keterangan \\
\hline 2 & Mata pelajaran & $\begin{array}{l}\text { RPP yang ditunjukkan guru merupakan RPP } \\
\text { yang sudah mengacu pada kurikulum 2013, } \\
\text { dimana sudah ada tema, subtema, pembelajaran } \\
\text { ke-berapa, dan juga alokasi waktu. }\end{array}$ \\
\hline 3 & Kelas/semester & RPP ini diperuntukkan untuk kelas II semester 2. \\
\hline 4 & Alokasi waktu & $\begin{array}{l}\text { Alokasi waktu yang dicantumkan } 6 \times 35 \text { menit ( } 1 \\
\text { pertemuan). }\end{array}$ \\
\hline 5 & Kompetensi inti & $\begin{array}{l}\text { Kompetensi inti ditulis lengkap mulai dari KI 1- } \\
4 \text { pada seluruh RPP. }\end{array}$ \\
\hline 6 & Kompetensi dasar & $\begin{array}{l}\text { Kompetensi dasar disusun sesuai dengan mata } \\
\text { pelajaran yang akan diajarkan pada hari itu, KD } \\
\text { dijabarkan tiap mata pelajaran. }\end{array}$ \\
\hline 7 & Indicator pencapaian kompetensi & $\begin{array}{l}\text { Penulisan isi indikator hanya tertulis tiap mata } \\
\text { pelajaran, tidak dijabarkan tiap } \\
\text { ranah/keterampilan, belum adanya penjabaran } \\
\text { ranah kognitif, psikomotorik, dan afektif. }\end{array}$ \\
\hline 8 & Materi pembelajaran & $\begin{array}{l}\text { Pada RPP sudah dicantumkan beberapa materi } \\
\text { tetapi hanya poin-poinnya saja. Penulisan materi } \\
\text { mengacu pada buku guru dan juga buku siswa. }\end{array}$ \\
\hline \multicolumn{3}{|c|}{ Kegiatan Pembelajaran } \\
\hline 9 & Kegiataan pendahuluan & $\begin{array}{l}\text { Pada kegiatan pendahuluan tercantum adanya } \\
\text { beberapa kegiaatan seperti memberikan salam, } \\
\text { mengecek kesiapan siswa, menginformasikan } \\
\text { tema, dan juga tahap-tahap dalam pendekatan } \\
\text { saintifik. }\end{array}$ \\
\hline 10 & Kegiatan inti & $\begin{array}{l}\text { Pada kegiatan ini tertulis adanya kegiatan seperti } \\
\text { membaca teks, bertanya jawab, mengamati } \\
\text { gambar, menuliskan laporan hasil pengamatan, } \\
\text { membacakan laporan, mencontohkan gerakan, } \\
\text { pemberian penguatan serta motivasi. }\end{array}$ \\
\hline 11 & Kegiatan penutup & $\begin{array}{l}\text { Pada kegiatan ini tercantum tahapan membuat } \\
\text { kesimpulan secara bersama-sama, memberikan } \\
\text { kesempatan pada peserta didik untuk } \\
\text { menyampaikan pendapatnya, dan evaluasi. }\end{array}$ \\
\hline \multicolumn{3}{|c|}{ Penilaian, Pembelajaran Remedial, dan Pengayaan } \\
\hline 12 & Teknik penilaian & $\begin{array}{l}\text { Teknik penilaian yang terdapat dalam RPP } \\
\text { adalah, observasi, tes, dan unjuk kerja. }\end{array}$ \\
\hline 13 & Instrument penilaian & $\begin{array}{l}\text { Instrument penilaian yang digunakan adalah } \\
\text { tabel penilaian sikap, penilaian pengetahuan, dan } \\
\text { penilaian keterampilan, }\end{array}$ \\
\hline 14 & Pembelajaran remedial dan pengayaan & $\begin{array}{l}\text { Pada kegiatan ini terdapat adanya tahapan } \\
\text { mengulas kembali tentang materi yang sudah } \\
\text { diajarkan. }\end{array}$ \\
\hline 15 & Media/alat, bahan, dan sumber belajar & $\begin{array}{l}\text { Sumber belajar yang tertulis di RPP adalah tema } \\
7 \text {, subtema } 4 \text {, dan pembelajaran ke-4. Media yang } \\
\text { digunakan gambar pada buku siswa. }\end{array}$ \\
\hline
\end{tabular}

Berdasarkan tabel di atas, komponen-komponen RPP yang ditunjukkan oleh ibu Ety sudah mengacu pada kurikulum 2013, hanya saja pada kegiatan pendahuluan tidak dijabarkan secara spesifik adanya ice breaking, pada kegiatan inti tidak dicantumkan tahapan sesuai dengan pendekatan saintifik (5M) yang biasanya di tuliskan keterangan 
Reninda, Analisis Proses Pembelajaran Pendekatan...

kegiatan dalam tanda kurung, tetapi secara penjabaran guru sudah menuliskan adanya kegiatan mengamati, menanya dan sebagainya.

Penjabaran komponen dalam Rencana Pelaksanaan Pembelajaran (RPP) dengan pendekatan saintifik belum sempurna, hal ini sesuai dengan hasil wawancara yang dilakukan oleh peneliti dengan guru sebagai berikut.

Peneliti : “Apakah di dalam RPP ini terdapat kegiatan 5M yang sesuai dengan pendekatan saintifk dalam kurikulum 2013?"

Guru : "iya terdapat kegiatan mengamati, menanya, tetapi belum lengkap 5M".

Peneliti : "Bagaimana gambaran pendekatan saintifik jika Ibu menyusun sendiri RPP tersebut?".

Guru : "Saya akan menelaah silabus, buku siswa, dan buku guru dahulu mbak, kemudian menganalisis kompetensi inti dan kompetensi dasar, kemudian menjabarkan indikator sesuai dengan tema/subtema. Dalam kegiatan pembelajaran saya akan berusaha menggunakan pendekatan saintifik yang terdiri dari 5 tahapan tersebut".

Keseluruhan isi dari RPP yang ditunjukkan oleh ibu Ety pada peneliti sudah mendekati tahapan 5M dalam kegiatan belajar mengajar, hanya saja untuk media, sumber belajar, dan bahan pembelajaran masih belum dikembangkan, sehingga Ibu Ety masih menggunakan buku guru dan buku siswa saja dalam proses pembelajaran yang tercantum dalam RPP tersebut.

\section{Pelaksanaan Pembelajaran}

Pada pelaksanaan pembelajaran Ibu Ety berusaha melaksanakan pembelajaran seperti tahapan yang tertulis dalam RPP. Hal ini sesuai dengan hasil wawancara peneliti dengan guru kelas II berikut ini.

Peneliti : “apakah proses pembelajaran yang dilaksnakan telah sesuai dengan RPP?".

Guru : "Saya berusaha sesuaikan dengan tahapan yang terdapat di RPP, walaupun kadang terkendala waktu dan aktivitas-aktivitas yang lainnya".

Dari hal tersebut dapat diketahui bahwa guru berusaha melaksanakan pembelajaran sesuai dengan RPP, walaupun masih ada kegiatan atau materi pembelajaran yang belum tersampaikan karena alokasi waktu yang tidak mencukupi. Sekolah juga memberikan dukungan fasilitas untuk membantu proses pelaksanaan pembelajaran. Hal ini sesuai dengan wawancara peneliti dengan kepala sekolah berikut ini.

Peneliti : "Apakah Bapak selalu memberikan dorongan kepada guru-guru untuk terus mempelajari tentang pendekatan saintifik dalam kurikulum 2013 untuk selalu diterapkan di segala kondisi?” 
Reninda, Analisis Proses Pembelajaran Pendekatan...

Kepala Sekolah :"Saya selalu mendukung guru-guru untuk terus belajar menggunakan pendekatan saintifik dalam proses pembelajaran, dukungan selain motivasi saya juga berusaha memfasilitasi guru-guru dalam menerapkan pendekatan saintifik, fasilitas itu berupa ATK, computer, internet, dan alat music drumband, saya berpikir bahwa memang guru-guru wajib di berikan fasilitas untuk mendukung proses pembelajaran".

Dari hasil observasi dan wawancara dapat diketahui bahwa sekolah memberikan dukungan berupa fasilitas yang antara lain adalah ATK, computer, internet, dan alat music drumband serta adanya perpustakaan sekolah. Selanjutnya, berdasarkan hasil observasi dan wawancara, ditemukan bahwa pelaksanaan pembelajaran menggunakan pendekatan saintifik dalam kurikulum 2013 yang dilaksanakan oleh Ibu Ety di kelas II terdiri dari kegiatan utama yaitu, kegiatan pendahuluan, kegiatan inti, dan kegiatan penutup. Berikut ini gambaran tentang pelaksanaan proses pembelajaran dengan pendekatan saintifik dalam kurikulum 2013 di kelas II SDN Jatidukuh. Berikut ini adalah tabel proses pembelajaran pendekatan saintifik yang dilakukan oleh guru.

\section{Tabel 3. Proses Pembelajaran Pendekatan Saintifik}

\begin{tabular}{|c|c|c|}
\hline No & Indikator & Deskripsi Hasil Temuan \\
\hline \multicolumn{3}{|c|}{ Kegiatan Pendahuluan } \\
\hline 1 & $\begin{array}{l}\text { Guru menkondisikan siswa serta suasana } \\
\text { belajar yang menyenangkan. }\end{array}$ & $\begin{array}{l}\text { Guru mempresensi siswa dan mengkondisikan } \\
\text { siswa untuk mengikuti kegiatan belajar } \\
\text { mengajar. }\end{array}$ \\
\hline 2 & $\begin{array}{l}\text { Guru mendiskusikan kompetensi yang sudah } \\
\text { dipelajari dan dikembangkan sebelumnya } \\
\text { berkaitan dengan kompetensi yang akan } \\
\text { dipelajari dan dikembangkan. }\end{array}$ & $\begin{array}{l}\text { Guru menyampaikan kompetensi yang akan } \\
\text { dipelajari. }\end{array}$ \\
\hline 3 & $\begin{array}{l}\text { Guru menyampaikan kompetensi yang akan } \\
\text { dicapai dan manfaatnya dalam kehidupan } \\
\text { sehari-hari. }\end{array}$ & $\begin{array}{l}\text { Guru menyampaikan kompetensi yang akan } \\
\text { dicapai pada hari itu. }\end{array}$ \\
\hline 4 & $\begin{array}{l}\text { Guru menyampaikan garis besar cakupan } \\
\text { materi dan kegiatan yang akan dilakukan. }\end{array}$ & $\begin{array}{l}\text { Guru menuliskan tentang materi yang akan } \\
\text { dipelajari, menjelaskan kegiatan-kegiatan } \\
\text { dalam pembelajaran. }\end{array}$ \\
\hline 5 & $\begin{array}{l}\text { Guru menyampaikan lingkup dan teknik } \\
\text { penilaian yang akan dilakukan. }\end{array}$ & $\begin{array}{l}\text { Guru tidak menyampaikan teknik } \\
\text { penilaian/evaluasi. }\end{array}$ \\
\hline \multicolumn{3}{|c|}{ Kegiatan Inti } \\
\hline \multirow[t]{3}{*}{6} & Mengamati (Pendekatan Saintifik) & \\
\hline & $\begin{array}{l}\text { 1. Guru memfasilitasi siswa untuk melakukan } \\
\text { proses pengamatan. }\end{array}$ & Guru memberikan buku bacaan terkait materi. \\
\hline & $\begin{array}{l}\text { 2. Siswa mengamati dengan indera (membaca, } \\
\text { mendengar, menyimak, melihat, menonton, } \\
\text { da sebagainya). }\end{array}$ & $\begin{array}{l}\text { Guru meminta siswa untuk mengamati gambar } \\
\text { yang terdapat dalam bacaan, dan meminta } \\
\text { beberapa siswa untuk membaca bacaan } \\
\text { tersebut secara bergantian. }\end{array}$ \\
\hline \multirow[t]{3}{*}{7} & Menanya (Pendekatan Saintifik) & \\
\hline & $\begin{array}{l}\text { 1. Guru memfasilitasi siswa untuk melakukan } \\
\text { kegiatan menanya. }\end{array}$ & $\begin{array}{l}\text { Guru memotivasi siswa agar mampu } \\
\text { mengemukakan pendapatnya } \\
\text { yang terdapat dalam bacaan. }\end{array}$ \\
\hline & $\begin{array}{l}\text { 2. Siswa membuat dan mengajukan pertanyaan } \\
\text { terkait materi yang disampikan oleh guru. }\end{array}$ & $\begin{array}{l}\text { Guru melakukan kegiatan Tanya jawab } \\
\text { bersama-sama dengan siswa. }\end{array}$ \\
\hline
\end{tabular}


Reninda, Analisis Proses Pembelajaran Pendekatan...

\begin{tabular}{|c|c|c|}
\hline \multirow[t]{3}{*}{8} & $\begin{array}{lll}\text { Mengumpulkan } & \text { informasi } & \text { (Pendekatan } \\
\text { Saintifik) } & & \\
\end{array}$ & \\
\hline & $\begin{array}{l}\text { 1. Guru memfasilitasi siswa untuk melakukan } \\
\text { kegiatan mengumpulkan informasi. }\end{array}$ & $\begin{array}{l}\text { Guru memberikan buku bacaan, memberikan } \\
\text { informasi secara lisan. }\end{array}$ \\
\hline & $\begin{array}{l}\text { 2. Siswa berdiskusi, mendemonstrasikan, } \\
\text { membaca sumber belajar, mengumpulkan } \\
\text { data dari berbagai sumber belajar. }\end{array}$ & $\begin{array}{l}\text { Siswa diminta untuk berkelompok, } \\
\text { mendiskusikan tugas-tugas yang diberikan, } \\
\text { membaca lagi buku bacaan yang diberikan } \\
\text { guru, serta memperbolehkan siswa bertanya } \\
\text { jika ada kesulitan. }\end{array}$ \\
\hline \multirow[t]{3}{*}{9} & Menalar/Mengasosiasi (Pendekatan Saintifik) & \\
\hline & $\begin{array}{l}\text { 1. Guru memfasilitasi siswa untuk melakukan } \\
\text { kegiatan menalar. }\end{array}$ & - \\
\hline & $\begin{array}{l}\text { 2. Siswa mengolah informasi yang sudah } \\
\text { dikumpulkan, mengkategorikan data, } \\
\text { menghubungkan dengan fenomena yang } \\
\text { terjadi dalam kehidupan sehari-hari, } \\
\text { menemukan suatu pola, dan membuat } \\
\text { kesimpulan. }\end{array}$ & $\begin{array}{l}\text { Siswa diminta untuk menuliskan informasi- } \\
\text { informasi yang diperoleh, kemudian diminta } \\
\text { juga untuk menuliskan kesimpulan dari } \\
\text { informasi yang diperoleh. }\end{array}$ \\
\hline \multirow[t]{4}{*}{10} & Mengkomunikasikan (Pendekatan Saintifik) & \\
\hline & $\begin{array}{l}\text { 1. Guru memfasilitasi siswa untuk melakukan } \\
\text { kegiatan mengkomunikasikan. }\end{array}$ & - \\
\hline & $\begin{array}{l}\text { 2. Siswa menyajikan laporan dalam bentuk } \\
\text { bagan, table, diagram, grafik, menyusun } \\
\text { laporan tertulis, dan menyajikan laporan } \\
\text { secara lisan. }\end{array}$ & $\begin{array}{l}\text { Siswa diminta untuk mempresentasikan hasil } \\
\text { kerja kelompoknya ke depan. }\end{array}$ \\
\hline & Kegiatan Penutup & \\
\hline 11 & $\begin{array}{l}\text { Guru bersama siswa membuat kesimpulan } \\
\text { secara bersama-sama. }\end{array}$ & - . \\
\hline 12 & $\begin{array}{l}\text { Guru bersama siswa melakukan refleksi } \\
\text { terhadap kegiatan yang sudah dilakukan. }\end{array}$ & - \\
\hline 13 & $\begin{array}{l}\text { Guru memberikan umpan balik terhadap proses } \\
\text { pembelajaran. }\end{array}$ & - \\
\hline 14 & Guru melakukan penilaian. & Melakukan penilaian yang berupa tes tulis. \\
\hline 15 & $\begin{array}{l}\text { Guru merencanakan kegiatan tindak lanjut } \\
\text { dalam bentuk pembelajaran remedi, program } \\
\text { pengayaan, layanan konseling, dan pemberian } \\
\text { tugas. }\end{array}$ & - \\
\hline
\end{tabular}

\section{Kegiatan Pendahuluan}

Berdasarkan hasil observasi, kegiatan pembelajaran yang dilakukan Ibu Ety dalam kegiatan pendahuluan antara lain adalah mengkondisikan siswa dan suasana belajar yang cukup menyenangkan, mendiskusikan kompetensi yang sudah dipelajari, menyampaikan komeptensi yang akan dicapai, menyampaikan garis besar cakupan materi, dan menyampaikan lingkup dan teknik penilaian yang akan digunakan alasan guru melakukan kegiatan tersebut adalah karena guru mendapatkan penjelasan tersebut saat mengikuti keiatan pelatihan dan sosialisasi. Hal ini sesuai dengan pernyataan guru dalam wawancara berikut ini. 
Reninda, Analisis Proses Pembelajaran Pendekatan...

Peneliti : "Apakah Ibu pernah mengikuti kegiatan pelatihan atau sosialisasi tentang pendekatan saintifik yang terdapat di dalam kurikulum 2013?"

Guru : "Iya, saya pernah mengikuti 3x pelatihan kurikulum 2013 yang di dalamnya terdapat penjelasan tentang $5 \mathrm{M}$ pada pendekatan saintifik".

\section{Kegiatan Inti}

Berdasarkan hasil observasi, wawancara, dan dokumentasi diperoleh data bahwa kegiatan inti yang dilakukan guru belum sepenuhnya menerapkan 5M dalam pendekatan saintifik. 5M dalam pendekatan saintifik adalah kegiatan mengamati, menanya, menalar, mengasosiasi, dan mengomunikasikan. Berikut ini penjelasan kegiatan 5M.

\section{Mengamati}

Berdasarkan hasil observasi, kegiatan mengamati yang dilakukan siswa yaitu mengamati gambar yang terdapat di dalam buku siswa dan membaca teks terkait materi. Dalam 3x observasi yang dilakukan peneliti, guru selalu menerapkan kegiatan-kegiatan yang sama.

\section{Menanya}

Berdasarkan hasil observasi, kegiatan menanya yang dilakukan siswa adalah melakukan Tanya jawab dengan guru terkait gambar atau teks bacaan dan membuat pertanyaan berdasarkan gambar atau berdasarkan teks bacaan. Berdasarkan hasil observasi dapat diketahui juga bahwa aktivitas guru pada kegiatan menanya ini adalah membimbing siswa untuk terlibat aktif dalam proses pembelajaran. Guru berusaha untuk memotivasi siswa agar mampu membuat pertanyaan atau guru memfasilitasi siswa untuk memunculkan beberapa pertanyaan. Contohnya aktivitas guru adalah berusaha mengkaitkan materi dengan fenomena yang terjadi dalam kehidupan sehari-hari siswa.

\section{Menalar}

Berdasarkan hasil observasi, kegiatan menalar yang dilakukan oleh siswa adalah menghubungkan informasi yang diperoleh agar menjadi informasi yang utuh untuk dapat diambil kesimpulan. Kegiatan menalar juga tidak lepas dari bimbingan dari guru. Aktivitas yang dilakukan oleh guru pada kegiatan ini adalah sebagai fasilitator untuk membantu siswa-siswi yang kesulitan dalam mengumpulkan informasi. Mulai dari meminta siswa untuk membaca buku siswa, meminta siswa untuk mengamati gambargambar yang terdapat di dalam buku bacaan yang telah disediakan. Sehingga menalar 
Reninda, Analisis Proses Pembelajaran Pendekatan...

dalam proses pembelajaran adalah menemukan jawaban dari pertanyaan-pertanyaan yang berkaitan dengan materi yang telah disampaikan oleh guru.

\section{Mengasosiasikan}

Berdasarkan hasil observasi, kegiatan mengasosiasi yang dilakukan siswa adalah mengembangkan apa yang diperoleh dari pembelajaran yang sedang dilakukan. Siswa diminta untuk mampu mengembangkan dan juga menerapkan hal-hal bermanfaat yang diperoleh dari pembelajaran di sekolah. Guru dalam kegiatan ini membimbing siswa untuk mampu mengembangkan pola berpikir. Guru membekali siswa dengan pengetahuan-pengetahuan yang akan ditemui dalam kehidupan sehari-hari.

\section{Mengomunikasikan}

Berdasarkan hasil observasi, kegiatan mengomunikasikan yang dilakukan siswa adalah membacakan hasil pekerjaannya/karyanya, menuliskan hasil diskusi, menuliskan hasil pekerjaannya di papan tulis, mengemukakan pendapatnya tentang penampilan teman-teman yang melakukan presentasi di depan. Berdasarkan hasil observasi, guru memberikan kesempatan siswa untuk mempresentasikan hasil pekerjaannya. Kemudian guru membimbing siswa untuk membahas hasil yang sudah disampaikan.

Selama kegiatan inti, guru dan siswa saling bekerjasama untuk menciptakan kondisi belajar mengajar yang aktif. Guru berusaha membantu siswa dalam menghadapi kesulitan-kesulitan yang dihadapi siswa. Guru berusaha membimbing siswa untuk memunculkan pertanyaan-pertanyaan terkait materi yang diajarkan. Hal ini sesuai dengan wawancara yang dilakukan peneliti dengan Guru Ey sebagai berikut.

Peneliti : “apakah dalam proses pembelajaran Ibu membimbing siswa dalam menghadapi kesulitankesulitan belajar?"

Guru : "Iya mbak, Saya berusaha untuk membantu kesulitan-kesulitan dalam proses pembelajaran, Saya mencoba membimbing siswa agar terus termotivasi untuk aktif dalam pembelajaran, dalam mengemukakan pendapat, dan dalam menyelesaikan permasalahan terkait materi pembelajaran, walaupun kadang anak suka bosan mendengar saya menyampaikan materi mungkin karena metode atau model yang saya gunakan kurang menarik".

\section{Kegiatan Penutup}

Berdasarkan hasil observasi, kegiatan penutup yang dilakukan guru dan siswa adalah bersama-sama membuat kesimpulan terkait materi yang telah dipelajari. Siswa diminta untuk mengemukakan pendapatnya sehubungan dengan materi yang telah disampaikan, kalau dirasa materi yang disampaikan guru kurang jelas, siswa 
Reninda, Analisis Proses Pembelajaran Pendekatan...

diperbolehkan untuk menanyakan kembali materi tersebut. Guru membimbing siswa untuk menyimpulkan materi, melakukan penilaian kinerja siswa. Penilaian yang dilakukan guru pada kegiatan penutup hanya terkait keterampilan kognitif, untuk keterampilan psikomotorik dan afektif guru tidak melakukan penilaian dalam proses pembelajaran. Guru juga jarang melakukan kegiatan umpan balik/refleksi. Hal ini sesuai dengan wawancara peneliti dengan guru, serta angket yang diberikan ke siswa kelas II.

Peneliti : "apakah dikegiatan penutup ibu selalu melakukan evaluasi, program pengayaan, ataupun kegiatan umpan balik?"

Guru : "Tidak setiap kali pembelajaran saya mengadakan kegiatan pengayaan, umpan balik/refleksi mbak dikarenakan kadanf waktunya tidak mencukupi, untuk penilaian saya hanya menilai aspek kognitifnya saja, aspek yang lain menyusul".

Hasil observasi dan wawancara ditemukan bahwa di kelas II SDN Jatidukuh dalam kegiatans penutup melakukan kegiatan penilaian dari tes yang diberikan. Refleksi, umpan balik, pengayaan, dan remedi tidak diberikan.

\section{Penilaian Pembelajaran Saintifik}

Hasil observasi ditemukan bahwa dalam penilaian pembelajaran kegiatan yang dilakukan oleh guru dalam penilaian pembelajaran yaitu guru kelas II tidak melakukan penilaian pada proses pembelajaran. Guru melakukan penilaian dari soal-soal tertulis yang terdapat di dalam buku siswa. Penilaian sikap dan keterampilan tidak dilakukan pada waktu kegiatan belajar-mengajar. Hal ini sesuai dengan wawancara yang dilakukan peneliti dan guru seperti berikut ini.

Peneliti : "Bagaimana proses penilaian pada siswa kelas II ya Bu?".

Guru : "Saya tidak pernah menilai saat kegiatan belajar mengajar berlangsung mbak, kalau untuk menilai soal-soal dari buku siswa memang biasanya langsung saya nilai, tapi kalau menilai sikap dan keterampilan tidak".

Hasil wawancara ini juga didukung dengan pernyataan Bapak Kepala sekolah yang mengatakan bahwa "Guru-guru disini sudah saya ikutkan kegiatan-kegiatan seperti pelatihan dan sosialisasi terkait pembelajaran dalam kurikulum 2013 mbak, hanya saja guru-guru mungkin sedikit kesulitan terkait waktu, saya berharap guru-guru disini berusaha untuk menerapkan apa yang sudah diperoleh dari berbagai pelatihan tersebut secara tepat, baik dalam perencanaan, pelaksanaan pembelajaran, maupun evaluasi pembelajaran di dalam kelas". 
Reninda, Analisis Proses Pembelajaran Pendekatan...

\section{Kendala-Kendala dalam Proses Pembelajaran}

Dari hasil observasi terdapat beberapa kendala yang dihadapi oleh guru dan siswa. Kendala yang dihadapi guru adalah terbatasnya waktu, pemahaman yang kurang tentang pembelajaran dengan pendekatan saintifik dalam kurikulum 2013, kegiatan-kegiatan 5M yang belum dilaksanakan karena belum terbiasa dilakukan oleh guru dan siswa, kurangnya informasi terhadap sumber-sumber belajar, dan guru cenderung masih menggunakan pembelajaran konvensional, dimana murid diminta masuk kelas, kemudian guru menjelaskan materi dan memberikan tugas tertulis pada siswa. Hal ini sesuai dengan wawancara antara peneliti dengan guru kelas II sebagai berikut.

Peneliti : "Kendala/kesulitan apa yang Ibu hadapi dalam proses pembelajaran dengan pendekatan saintifik?"

Guru : "kendala pertama yang saya hadapi adalah waktu mbak, kemudian sumber belajar yang terbatas, saya juga masih bingung dengan kegiatan dalam pendekatan saintifik".

Peneliti : “Apakah Ibu masih sering menggunakan pembelajaran konvensional dalam kelas?”

Guru : "Saya masih sering menggunakan pembelajaran konvensional tetapi kadang masih saya kolaborasi dengan kegiatan berdiskusi dan presentasi”.

Kendala-kendala yang dihadapi guru-guru ini juga dijelaskan oleh Bapak kepala sekolah saat wawancara dengan peneliti. Wawancaranya adalah sebagai berikut.

Peneliti : "Apakah guru-guru disini sering mengeluhkan sulitnya menerapkan pendekatan pembelajaran dalam kurikulum 2013 Pak?"

Kepala Sekolah : "Iya mbak, guru-guru memang kadang mengeluhkan ribetnya kegiatan pembelajaran yang diusung oleh kurikulum 2013, tidak hanya ribet dan membingungkan untuk guru-guru dalam proses pembelajarannya, tetapi dalam penyusunan RPPnya juga guru mengeluhkan kesulitan. Saya rasa karena guru-guru disini belum terbiasa, tetapi saya masih terus memotivasi mereka untuk mau belajar menerapkan hal-hal yang terdapat di dalam kurikulum 2013, seperti pendekatan saintifik".

\section{PEMBAHASAN}

\section{Perencanaan Pembelajaran Saintifik}

Hasil penelitian, guru tidak membuat Rencana Pelaksanaan Pembelajaran (RPP) sendiri sebelum pelaksanaan pembelajaran. Hal ini dikarenakan guru tidak mempunyai banyak waktu untuk menyusun Rencana Pelaksanaan Pembelajaran (RPP). Selain karena alasan waktu, guru juga merasa dirinya kurang mampu untuk menyusun RPP, 
Reninda, Analisis Proses Pembelajaran Pendekatan...

dikarenakan guru merasa kebingungan ketika harus memasukkan ranah kognitif, afektif, dan psikomotorik. Tidak berhenti pada penyusunan indikator, yang membuat bingung guru adalah menentukan kegiatan $5 \mathrm{M}$ pada pendekatan saintifik dalam proses pembelajaran.

Berdasarkan hasil analisis dokumen Rencana Pelaksanaan Pembelajaran (RPP) yang ditunjukkan oleh guru, secara komponen-komponen RPP sudah lengkap. Terdapat identitas RPP, kegiatan-kegiatan yang akan dilakukan (kegaiatan pendahuluan, kegiatan inti, dan kegiatan penutup). Pada kegaiatan inti sudah tertulis kegiatan 5M, tetapi keterangan kegiatan dalam kurung belum ada. Permasalahan dan alasan terkait penyusunan RPP ini juga ditemukan serupa seperti pada penelitian Aka (2012), dimana sebagian besar guru kurang dalam memerhatikan aspek penyusunan RPP ini, mereka cenderung merasa kurang memiliki waktu dan sumber-sumber rujukan lainnya.

\section{Pelaksanaan Pembelajaran Saintifik}

Hasil observasi dan juga wawancara pelaksanaan pembelajaran pendekatan saintifik yang dilakukan di kelas II kurang maksimal. Hal ini dikarenakan pendekatan saintifik masih susah untuk diterapkan di SDN tersebut. Siswa belum terbiasa, sehingga dalam pelaksanaan pembelajaran siswa sulit untuk mengikuti tahapan-tahapan kegiatan yang diinformasikan oleh guru. Pada pelaksanaan pembelajaran di kegiatan pendahuluan, guru sudah mengkondisikan siswa, mulai dari mengabsen hingga menciptakan suasana belajar yang nyaman dan menyenangkan. Menyampaikan kompetensi yang akan dicapai, menjelaskan kegiatan-kegiatan yang akan dilakukan, dan mengulas kembali materimateri sebelumnya.

Pada kegiatan inti, siswa sudah diminta untuk melakukan kegiatan pengamatan, seperti mengamati gambar yang diberikan oleh guru yang kemudian di bawah gambar terdapat bacaan yang juga harus dicermati oleh siswa. Kegiatan menanya, guru berusaha memotivasi siswa agar mampu bertanya dengan kalimat yang tepat. Cara guru memotivasi siswa dalam kegiatan menanya adalah mengkaitkan dengan sumber belajar yang terdapat di dalam lingkungan sekolah. Dalam kegiatan menalar siswa diajak untuk bertanya jawab yang dikaitkan dengan kehidupan sehari-harinya, kemudian diminta untuk memberikan contoh terkait materi yang dibahas. Pada kegiatan menalar ini siswa tidak begitu aktif menyampaikan pendapatnya, mereka cenderung pasif dalam proses pembelajaran. Kegiatan mengasosiasi dan mengomunikasikan menurut hasil 
Reninda, Analisis Proses Pembelajaran Pendekatan... pengamatan, observasi, dan wawancara memang jarang dilakukan. Alasannya karena waktu yang tidak cukup, sumber belajar yang terbatas, dan juga guru yang masih menyukai pembelajaran konvensional.

Pada kegiatan penutup yang dilakukan siswa adalah menunjukkan hasil kerjanya kepada guru, kemudian guru menilai tanpa ada kegiatan membuat kesimpulan bersama siswa, refleksi, umpan balik, program pengayaan, atau remedi.

\section{Penilaian Pembelajaran Pendekatan Saintifik}

Berdasarkan hasil penelitian, guru tidak melakukan penilaian dalam kompetensi pengetahuan, sikap, dan psikomotoriknya. Guru menilai dari tes tertulis yang berupa soalsoal berdasarkan buku siswa. Guru juga memberikan tugas untuk dikerjakan dirumah berdasarkan buku siswa.

Hal seperti ini kurang sesuai dengan lampiran Permendikbud No 23 tahun 2016 tentang standar penilaian, bahwa dalam tes tulis harus disertai dengan pedoman penskoran, karena penilaian dalam pendekatan saintifik sifatnya adalah transparan/terbuka, sehingga semua pihak dapat mengetahui nilai dari masing-masing siswa. Akan tetapi dalam pelaksanaannya guru tidak menggunakan instrument-instrumen penilaian seperti yang tertera pada lampiran Permendikbud tersebut. Hal ini menunjukkan bahwa guru belum memahami pentingnya instrumen yang berupa pedoman penskoran, rubrik, dan kisi-kisi dalam penilaian pada proses pembelajaran.

\section{Kendala-Kendala dalam Proses Pembelajaran}

Hasil penelitian tentang kendala yang dihadapi saat proses pembelajaran dengan pendekatan saintifik dalam kurikulum 2013 sebagai berikut.

1. Terbatasnya waktu.

2. Guru merasa kebingungan saat menghubungkan antara pembelajaran satu dengan yang lainnya.

3. Guru dan siswa tidak terbiasanya menerapkan pendekatan saintifik.

4. Pemahaman guru yang kurang akan informasi pendekatan saintifik dalam kegiatan belajar mengajar.

5. Masih menggunakan pembelajaran konvensional.

6. Sumber belajar yang dirasa masih terbatas.

\section{UCAPAN TERIMA KASIH}


Reninda, Analisis Proses Pembelajaran Pendekatan...

Terimakasih kepada semua pihak Universitas Abdurachman Saleh Situbondo, Bapak Noto Purwo selaku Kepala Sekolah, Ibu Ety selaku guru kelas II, dan siswa-siswi kelas II SDN Jatidukuh Mojokerto yang telah membantu terlaksananya penelitian dan penyusunan laporan ini. Penulis berharap semoga laporan penelitian ini membawa banyak manfaat bagi kita semua

\section{SIMPULAN}

Berdasarkan hasil dan pembahasan, maka penelitian ini dapat disimpulkan bahwa di SDN Jatidukuh Mojokerto khususnya kelas II belum sepenuhnya menerapkan pendekatan saintifik sesuai dengan ketentuan yang terdapat di dalam kurikulum 2013. Baik dari perencanaan pembelajaran, pelaksanaan pembelajaran, dan penilaian pembelajaran belum dilaksanakannya secara maksimal. Hal ini dikarenakan adanya kendala-kendala yang dihadapi oleh guru, salah satunya adalah terbatasnya waktu yang ada. Sehingga perlu adanya perbaikan dan monitoring dari pihak stakeholder yang terdapat di sekolah tersebut guna meningkat kualitas pembelajaran yang efektif dan efesien, serta sesuai dengan perkembangan IPTEK.

\section{DAFTAR PUSTAKA}

Aka, K. A. (2012). Problematika Pembelajaran PKn Pada Kelas IV SDN Segugus IV Kecamatan Kedungkandang Malang. SKRIPSI Jurusan Kependidikan Sekolah Dasar \& Prasekolah-Fakultas Ilmu Pendidikan UM.

Arikunto, Suharsimi. 2006. Prosedur Penelitian Suatu Pendekatan Praktik Edisi Revisi. Rineka Cipta. Jakarta.

Afandi, A. N. H., \& Aka, K. A. (2019). Pengembangan dan Validasi Instrumen Analisis Buku Tematik-Terpadu pada Kurikulum 2013. Jurnal Pendidikan Dasar NusantarA, 4(2), 199-219.

Daryanto. 2014. Pendekatan Pembelajaran Saintifik Kurikulum 2013. Yogyakarta: Gava Media

Hosnan. 2014. Pendekatan Saintifik dan Kontekstual dalam Pembelajaran Abad 21. Bogor: Ghalia Indonesia

Miles, B. Mathew dan Michael Huberman. 1992. Analisis Data Kualitatif Buku Sumber Tentang Metode-metode Baru. Jakarta: UIP. 
Reninda, Analisis Proses Pembelajaran Pendekatan... Permendikbud No 22 Tahun 2016 tentang Standar Proses

Permendikbud No 23 Tahun 2016 tentang Standar Penilaian

Sugiyono. 2016. Metode Penelitian Pendidikan. Jakarta: Alfabeta. 